УДК 621.742 .486

\author{
Л.І. Солоненко ${ }^{1}$, С.І. Реп'я ${ }^{2}$ \\ ${ }^{1}$ Одеський національний політехнічний університет \\ ${ }^{2}$ Національна металургійна академія України
}

\title{
МІЦНІСТЬ ПІЩАНО-РІДКОСКЛЯНИХ СУМІШЕЙ, ЩО СТРУКТУРУВАЛИ ПАРО-МІКРОХВИЛЬОВОЮ ОБРОБКОЮ
}

\begin{abstract}
Робота присвячена дослідженням впливу умов плакування кварцового піску натрієвим рідким склом, тривалості зберігання плакованого піску і параметрів паромікрохвильового впливу на плакований пісок на межу його міцності при стисненні в структурованому стані. Встановлено, що тривале (протягом року) зберігання плакованого піску в герметичній тарі призводить до значного зниження (в 2 ... 3 рази в порівнянні зі свіжоплакованою сумішшю) межі міцності при стисненні структурованого піску. Рекомендовано для структурування суміші за способом паромікрохвильового затвердіння використовувати свіжеплакований кварцовий пісок 3 початковою температурою $20 \ldots 26^{\circ} \mathrm{C}$, для плакування використовувати кварцовий пісок з вмістом води до 0,2 \% води (за масою) і сушити його в плакованому стані до вмісту вологи в затверділому рідкому склі не більше 2 ... 3 \% від маси гідратованого силікату натрію.
\end{abstract}

DOI: $10.34185 / 0543-5749.2020-3-39-47$

\section{Вступ}

У числі показників, які зумовлюють технологічність, обсипальність, ймовірність утворення на виливках поверхневих дефектів, витрати на вибивання і очищення виливків тощо одноразових ливарних форм і стрижнів (ЛФС), $\epsilon$ межа міцності їх структурованої суміші $[1,2]$.

Міцність суміші залежить від природи, властивостей і кількості сполучного матеріалу, а також від іï величини адгезії та когезії, способу ii структурування, фракційного складу піску, ступеня його ущільнення і т.п. [3, 4].

Класичним напрямком збільшення міцності будь-якої структурованої суміші є підвищення міцності ¥іi одиничного контакту - манжети (сполучного матеріалу між сусідніми піщинками у суміші) [5]. Тобто, з цієї точки зору найбільш радикальним способом підвищення міцності будь-якої суміші є збільшення в ній масового вмісту сполучного матеріалу [6]. Проте, даний напрямок вирішення завдання підвищення міцності не завжди виявляється прийнятним.
Зокрема, збільшення вмісту рідкого скла (РС) в піщано-рідкоскляній суміші (ПРС) призводить не тільки до збільшення іiі міцності, але і до підвищення роботи ії вибивання з виливків $[7,8]$. 3 метою зниження роботи вибивання стрижнів 3 виливків автори $[7,9,10]$ рекомендують зменшити вміст РС в суміші з $5 \ldots 8 \%$ до $2 . .3 \%$ за масою. Однак, як показує практика використання ПРС, зменшення в суміші РС, структурованої в результаті продування суміші вуглекислим газом або введення до складу суміші хімічно активної речовини, не забезпечує їй необхідну технологічну міцність, а ЛФС з таких сумішей характеризуються ще й високою обсипальністю. У той же час, теплова сушка ПРС зі зниженим вмістом РС, забезпечуючи суміші необхідний рівень міцності, обсипальності і задовільне вибивання, але вона енергоємна, нетехнологічна $\mathrm{i}$ тривала в часі.

У зв'язку з цим для зниження роботи вибивання в ПРС $з$ високим вмістом РС вводять технологічні добавки, в числі яких: спирти, карбонати, гідрол, декстрин, бітум, вугілля, кокс, ве-

(C) Солоненко Л.І., Реп'ях C.I., 2020 
рмикуліт, папір, дерев'яна тирса і ін. [11...16]. Негативний результат використання таких добавок - різке збільшення витрат на регенерацію відпрацьованої суміші, що і є причиною відсутності рециклінгу кварцового піску в ливарних цехах.

\section{Постановка проблеми}

На сьогоднішній день 3 числа відомих способів структурування ПРС найменш дослідженим, але найбільш перспективним є спосіб паромікрохвильового затвердіння (ПМЗ), що поєднує переваги зазначених вище способів затвердіння сумішей. Тим не менш, у даний час відсутні дані про вплив на міцність ПРС, структурованих за ПМЗ-процесом, умов плакування кварцового піску РС, параметрів структурування суміші, масового вмісту РС в суміші, терміну та умов iї зберігання тощо.

Завдання досліджень - оцінка впливу на межу міцності при стисненні суміші, структурованої за ПМЗ-процесом, використовуваного для плакування кварцового піску, вологості кварцового піску до його плакування РС, терміну зберігання суміші в герметичній тарі, початкової температури суміші.

Мета роботи. Встановлення закономірностей впливу умов плакування кварцового піску РC, параметрів ПМЗ-процесу і терміну зберігання суміші на величину іiі межі міцності при стисненні.

\section{Об'єкт і методика досліджень}

Об'єкт досліджень - межа міцності при стисненні структурованого способом ПМЗ кварцового піску, попередньо плакованого натрієвим РС.

У дослідженнях використовували кварцовий пісок з вмістом глинистої складової менше $0,5 \%$ за масою і переважним розміром піщинок 0,23 мм, плакований содовим натрієвим РС (ГОСТ 13078-81) 3 силікатним модулем $2,8 \ldots 3,0$ і питомою щільністю $1,43 \ldots 1,46$ г/ $\mathrm{cm}^{3}$. Для фарбування піску в РС вводили чорнило червоного кольору. Для визначення навантаження руйнування структурованих сумішей при стисканні за способом ПМЗ виготовляли зразки розмірами $\varnothing 50 \times 50$ мм, а також $\varnothing 30 \times 30$ мм. Випробування зразків проводили на приладі LRu-2e. Для дослідження впливу вологості кварцового піску на межу міцності структурованих сумішей за способом ПМЗ в кварцовий пісок вводили 0,2 ...5,0 \% (за масою) дистильованої води і перемішували, потім для плакування в суміш вводили відповідну кількість РС і здійснювали сушку до вмісту води в плакованому шарі менш $18 \%$ (за масою). Структурування суміші проводили мікрохвильовим випромінюванням при номінальній потужності магнетрона 900 Вт і частотою випромінювання 2450 МГц, використовуючи наважку води масою 1 г. Температуру вимірювали електронним потенціометром 3 точністю $\pm 1{ }^{\circ} \mathrm{C}$ в комплекті з контактною хромель-капелевою термопарою, що має діаметр електродів 0,2 мм. Зберігання плакованих пісків проводили при температурі $20 \ldots 25^{\circ} \mathrm{C}$ в пластиковій герметично закритій тарі.

\section{Результати досліджень}

За результатами виконаних досліджень встановлено, що на рівень межі міцності суміші при іiі стисненні, при інших рівних умовах, істотно впливає як початкова (до плакування) вологість кварцового піску, так і вологість плакованого шару на кварцовому піску, про що свідчать залежності на рис. 1.

3 аналізу залежностей на рис. 1 випливає, що зі збільшенням вологості піску до та після його плакування міцність структурованої суміші за ПМЗ-процесом зменшується. 3 цієї причини для реалізації структурування за способом ПМЗ доцільно використовувати кварцовий пісок для плакування РС 3 початковою вологістю до $0,2 \%$, який після сушіння на повітрі додатково сушать у полі мікрохвильового випромінювання, тим самим знижуючи вміст води в плакованому шарі 3 17...20\% (за масою плакованого шару) до $2 . . .3 \%$.

Така залежність від вологості неплакованого піску (див. рис. 1) пояснюється тим, що будьяка піщинка кварцового піску 1 (див. рис. 2,a) має n-ну кількість мікропор 2. При плакуванні, мікропорами 2 вологої піщинки 1 (див. рис. 2,б), 3 розташованою в ній водою 4 щільно покривається шаром РС 5 (див. рис. 2,в).

Тобто, по суті, по закінченні плакування вода в мікропорах піщинок виявляється «запечатаною» шаром висушеного РС. При структуруванні по ПМЗ-процесу відбувається об'ємний нагрів суміші, при якому нагріванню піддається і вода в мікропорах. При нагріванні вода в мікропорі в результаті закипання переходить у спінений стан 6 (рис. 2,г). 


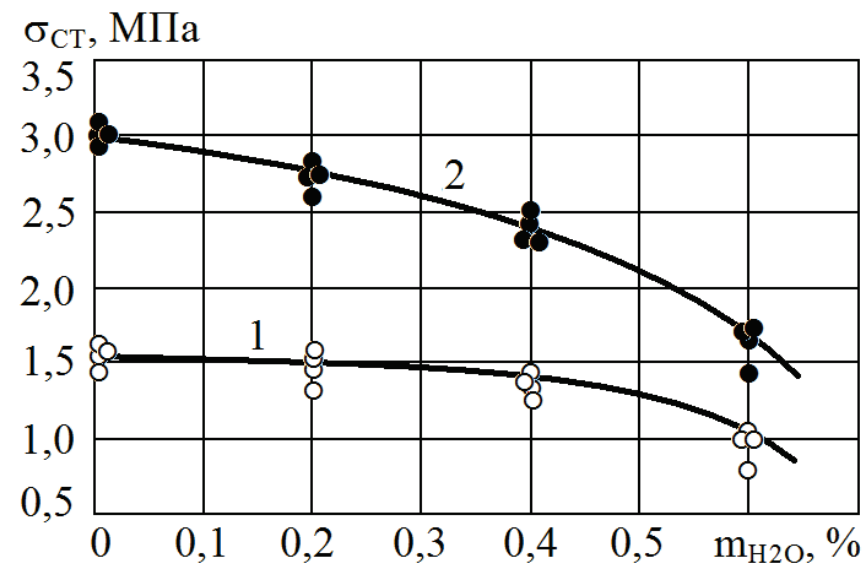

Рис. 1. Залежність межі міцності при стисненні ПРС, структурованої протягом 3 хв за способом ПМЗ з 1 \% РС (за масою, понад 100 \% піску), використаного для плакування ii кварцового піску, від вологості кварцового піску до його плакування: 1 - сушіння 1 год на повітрі; 2 - сушіння 1 год на повітрі та сушіння 3 хв в мікрохвильовій печі

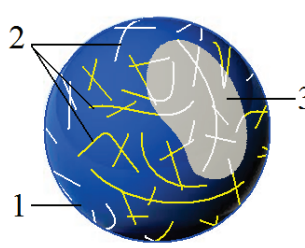

a

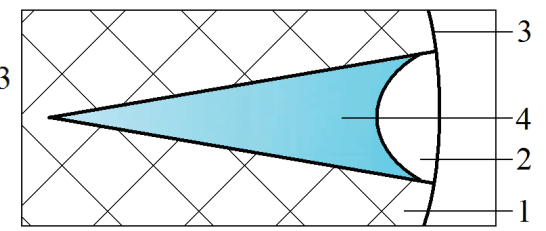

б

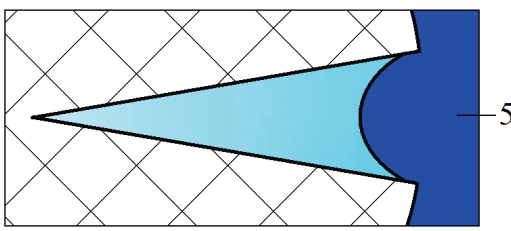

B

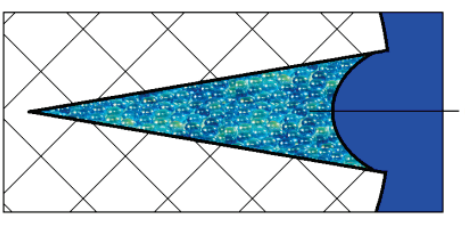

$\Gamma$

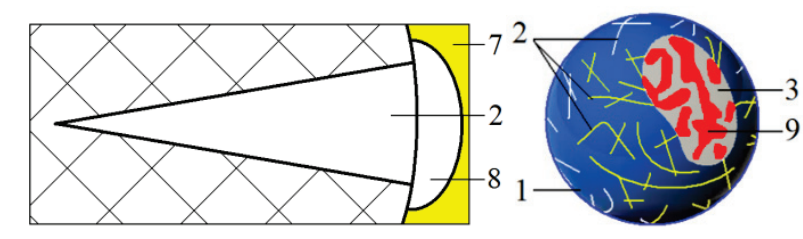

Д

e

Рис. 2. Схема плакованого вологого піску РС: 1 - піщинка; 2 - мікропора; 3 - місце контакту (манжета) плакованих піщинок РС; 4 - вода; 5 - РС; 6 - спінена вода; 7 - дегідратоване РС; 8 - збільшена в об'ємі вода; 9 - місце підриву манжети

Збільшуючись в об'ємі, вода і її пар 8 підривають плакований шар РС 7 на піщинці 1 (рис. 2,д). При структуруванні за ПМЗпроцесом, гідратоване РС під дією капілярних сил 3 плакованої піщинки стікає в місця контакту 3, утворюючи між ними манжети. Якщо пісок до плакування був вологим, то при структуруванні, ця волога, збільшуючись в об'ємі, послаблює адгезійне зчеплення рідкоскляних манжет піщинок в місцях підриву 9 (рис. 2,e), що, в свою чергу, знижує адгезійну складову міцності структурованої суміші.

Залежність міцності від вмісту вологи у плакованому шарі пояснюється структурою манжет, що формуються за ПМЗ-процесом. Чим вище вміст води у плакованому шарі, тим вище вірогідність утворення в структурованій суміші піноподібних манжет або структур, що і призводить до зниження іiі міцності.

Вплив терміну зберігання та початкової температури структурованого плакованого $3 \%$ РС (за масою, понад $100 \%$ піску) кварцового піску протягом 3 хв мікрохвильовим випромінюванням на величину межі міцності при стисненні представлено на рис. 3 . 


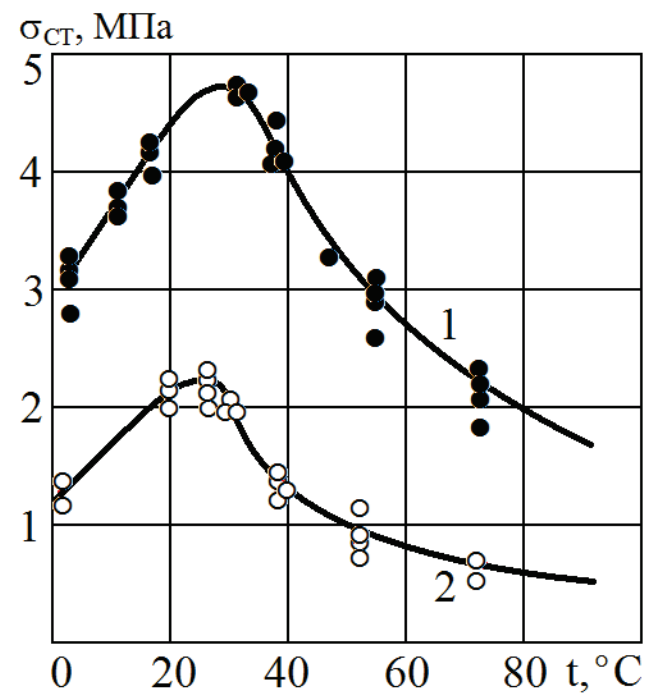

Рис. 3. Залежність межі міцності при стисненні структурованого плакованого кварцового піску від початкової температури (1 - термін зберігання плакованого піску на повітрі - 1 день; 2 - термін зберігання плакованого піску в герметичній тарі - 1 рік)

3 аналізу ходу залежностей на рис. 3 випливає, що межа міцності при стисненні в результаті тривалого зберігання плакованого піску навіть в герметично закритій тарі зменшується в $2 . . .3$ рази в порівнянні з свіжовиготовленою сумішшю. Ця закономірність пояснюється тим, що навіть при зберіганні в герметично закритій тарі, вуглекислий газ, що залишився в повітрі, призводить до часткової карбонізації РС, що втрачає нормальний стан, хімічний склад РС, і відповідно, межа міцності структурованої суміші. При цьому, максимальні значення межі міцності мають суміші, структуровані 3 початковою температурою піску $20 \ldots 26^{\circ} \mathrm{C}$. Зниження межі міцності суміші, структурованої 3 початковою температурою понад $26{ }^{\circ} \mathrm{C}$, по-видимому, пов'язано зі зниженням об'єму конденсату, що виділяється на піщинах в процесі ПМЗ. Тобто, ця обставина не дозволяє в повній мірі реалізувати насичення РС водою і, відповідно, сформувати великі манжети між ними. У той же час зниження початкової температури плакованого піску нижче $20{ }^{\circ} \mathrm{C}$ так само призводить до зменшення межі міцності структурованої суміші. В даному випадку, очевидно, це пов'язано з обмеженням тривалості структурування і незавершеністю процесу дегідратації РС.

Одним 3 показників стабільності ЛФС є величина межі їх міцності в різних частинах ливарної форми або стрижня. 3 цією метою плакована суміш $3 \%$ PC (за масою, понад
100 \% піску) і початковою температурою 2, 10 , $20,26,35,76^{\circ} \mathrm{C}$, яка зберігалася в герметичній тарі - 1 рік, структурували протягом 3 хв за ПМЗ-процесом в циліндричних витрусних ящиках $\varnothing 30 \times 220$ мм. Після закінчення структурування стрижні розрізали поперек на короткі циліндри $(\varnothing 30 \times 30$ мм) і визначали їх міцність. Отримані залежності представлені на рис. 4 , а вид стрижнів і структури їх поперечного перерізу, представлені на рис. 5.

Аналогічним чином надходили зі стрижнями, виготовленими 3 свіжеплакованого кварцового піску. Встановлено, що стрижні з свіжеплакованого кварцового піску володіють високим і постійним по довжині рівнем межі міцності при стисненні.

У той же час (див. рис. 5) міцність стрижнів, які структуровані із плакованого кварцового піску, що довго зберігався, неухильно зменшується з видаленням від місця розміщення в суміші водяного заряду. При цьому, найбільшою міцністю характеризуються стрижні 3 початковою температурою $20{ }^{\circ} \mathrm{C}$ i $26{ }^{\circ} \mathrm{C}$, а за результатами візуальної оцінки (див. рис. 5) найвищу якість поверхні у стрижнів, початкова температура яких до структурування за способом ПМЗ становила $47^{\circ} \mathrm{C}$. Причиною даної закономірності, мабуть, є процеси конденсації водяної пари на поверхні стрижневого ящика, зумовлені особливостями нагріву тіл в поле мікрохвильового випромінювання. 


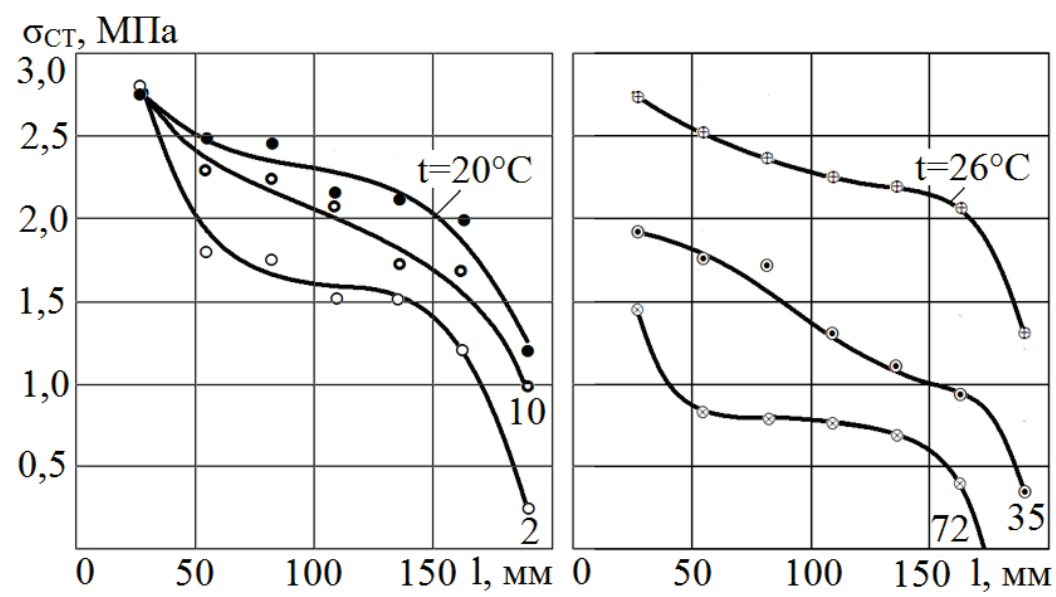

Рис. 4. Залежності величини межі міцності при стисненні структурованого плакованого кварцового піску від віддалення від водяного заряду в суміші і початкової температури (термін зберігання плакованого піску в герметичній тарі - 1 рік)

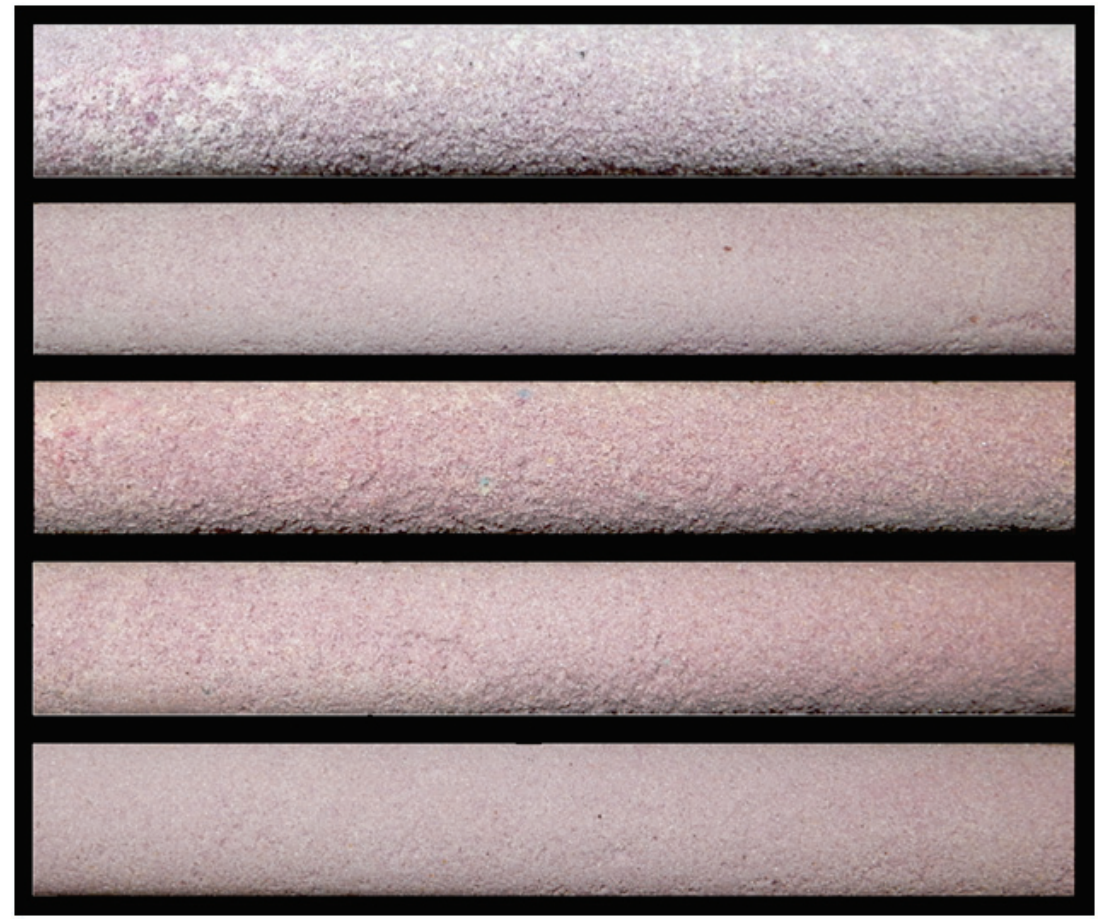

a

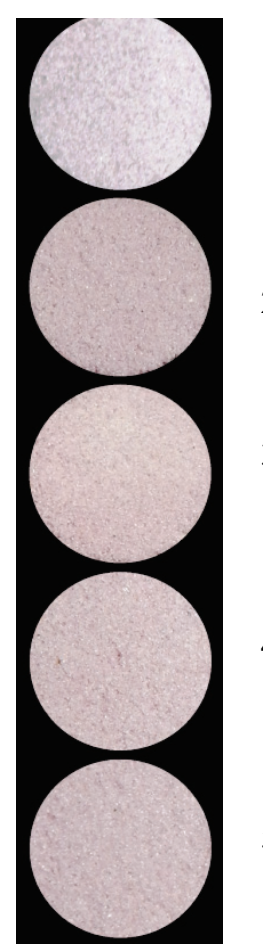

6

Рис. 5. Вид стрижнів (а) і їх структури в поперечному перерізі (б), виготовлених за способом ПМЗ з початковою температурою $2{ }^{\circ} \mathrm{C}(1), 10{ }^{\circ} \mathrm{C}(2), 20{ }^{\circ} \mathrm{C}(3), 35^{\circ} \mathrm{C}(4) \mathrm{i}$ $47^{\circ} \mathrm{C}(5)$ (зберігання плакованого піску -1 рік)

\section{Висновки і перспективи досліджень}

1. Плакування кварцового піску рідким склом для його подальшого структурування за способом ПМЗ слід здійснювати при утриманні в піску вологи не більше 0,2 \% (за масою) 3 наступним сушінням піску до вмісту вологи в плакованому шарі не більше $2 . .3 \%$ від маси гідратованого силікату натрію.
2. Оскільки межа міцності при стисненні в результаті тривалого зберігання плакованого піску навіть в герметично закритій тарі зменшується в 2...3 рази в порівнянні з свіжовиготовленою сумішшю, для структурування піщанорідкоскляної суміші за способом ПМЗ слід використовувати свіжовиготовлений плакований $0,5 \ldots 2,5 \%$ РС кварцовий пісок, а його темпера- 
тура до моменту початку структурування повинна складати $20 \ldots 26^{\circ} \mathrm{C}$.

Встановлені закономірності процесу ПМЗ є невеликою частиною даного перспективного напрямку структурування ЛФС. У зв'язку з цим перспективами досліджень буде встановлення закономірностей зміни властивостей таких сумішей, умов їх виробництва, відстеження віртуального «дрейфу» оптимуму комплексу їх основних властивостей і якості ЛФС при зміні умов їх виготовлення, підготовки до застосування, зберігання і т.п.

\section{Бібліографічний список}

1. Давиденко А. К., Иванов Б. К., Охрименко Г. П., Пономаренко О. И. Самотвердеющие жидкостекольные формовочно-стержневые смеси для изготовления отливок энергетического оборудования. Металл и литье Украиньл. 2018. № 3-4. C. 34-39.

2. Курын М. Г. Определение оптимальных характеристик жидкого стекла для процесса омагничивания жидкостекольных смесей. Технологический аудит и резервы производства. 2011. № 2(2). С. 14-20.

3. Дорошенко С. П. Повышение термостойкости ХТС. Литейное производство. 1984. № . C. 12-13.

4. Иванов А. А., Ромашкин В. Н. Упрочнение жидкостекольных смесей и внутрение напряжения в связующих. Литейное производство. 1984. № 7. С. 13-14.

5. Жуковский С. С., Ромашкин В. Н. О «шаровой» модели структуры формовочной смеси. Литейное производство. 1986. № 3. C. 12-13.

6. Великанов Г. Ф., Примак Н. Н., Бречко А. А. Прочность формовочной смеси. Литейное производство. 1986. № 3. С. 10-12.

7. Драпела В., Русин К. Свойства самотвердеющих смесей на базе жидкого стекла и жидкого отвердителя. Литейное производство. 1990. № 2. С. 20-21.

8. Жуковский С. С. Прочность литейной формы. М.: Машиностроение. 1989. 288 с.

9. Шувалов В. Г., Чичкан В. П. Смеси для $\mathrm{CO}_{2}$-процесса с низким содержанием связующего. Литейное производство. 1990. № 2. С. 19-20.

10. Морозов И. В., Чернявская М. Г., Аверин Е. К., Виткевич Н. Д., Лубенец А. П. Современное направление улучшения выбиваемости жидкостекольных смесей. Литейное произ- водство. 1984. № 2. С. 17-18.

11. Крутилин А. Н., Гуминский Ю. Ю., Русевич О. А. Повышение эффективности использования жидкостекольной смеси. Обзорная информация. Ч.1. Модифицирование. Литейное производство. 2018. № 1(90). С. 47-54.

12. Белобров Е. А., Карпенко О. Л., Белобров Л. Е. Вспомним забытые технологии: о выбиваемость жидкостекольных смесей из отливок. Литье Украиныл. 2018. № 6. С. 22-25.

13. Крутилин А. Н., Гуминский Ю. Ю., Русевич О. А. Повышение эффективности использования жидкостекольной смеси. Ч.3. Нанодисперсные материалы. Литейное производство. 2018. № 3(92). С. 31-35.

14. Линецкий Б. С., Мельник О. В., Кантор С. Б., Касьянов И. М. Легковыбиваемые малоотходные жидкостекольные формовочные стержни. Литейное производство. 1983. № 1. C. 18-19.

15. Жуковский С. С., Борсук П. А. Перспективы применения смесей с жидким стеклом в литейном производстве. Литейное производство. 1983. № 1. С. 12-14.

16. Гоберис С., Антонович В. Влияние добавок на свойства жидкостекольных композиций. Литейное производство. 2002. № 8. С. 22-24.

17. Реп'ях С. І., Солоненко Л. І., Білий О. П. Властивості і структури компонентів піщанорідко скляних формувальних сумішей. Теорія $i$ практика металургії. 2019. № 1. С. 81-92.

\section{References}

1. Davidenko, A. K., \& Ivanov, B. K., Okhrimenko, G. P., Ponomarenko, O. I. (2018). Selfhardening liquid glass molding-rod mixtures for the manufacture of castings of power equipment. Metal and casting of Ukraine, (3-4), 34-39

2. Kuryn, M. G. (2011). Determination of optimal characteristics of liquid glass for the magnetization process of liquid glass mixtures. Technological audit and production reserves, 2(2), 14-20

3. Doroshenko, S. P. (1984). Increasing the thermal stability of the cold storage system. Foundry, (7), 12-13

4. Ivanov, A. A., \& Romashkin, V. N. (1984). Strengthening liquid glass mixtures and internal stress in binders. Foundry, (7), 13-14

5. Zhukovskiy, S. S., \& Romashkin, V. N. (1986). About the "ball" model of the structure of the molding mixture. Foundry, (3), 12-13

6. Velikanov, G. F., Primak, N. N., \& Brech- 
ko, A. A. (1986). Strength of the molding mixture. Foundry, (3), 10-12

7. Drapela, V., \& Rusin, K. (1990). Properties of self-hardening mixtures based on liquid glass and liquid hardener. Foundry, (2), 20-21

8. Zhukovsky, S. S. (1989). Strength of the casting form. Moskva: Mechanical engineering

9. Shuvalov, V. G., \& Chichkan, V. P. (1990). Mixtures for a $\mathrm{CO}_{2}$-process with a low binder content. Foundry, (2), 19-20

10. Morozov, I. V., Chernyavskaya, M. G., Averin, E. K., Vitkevich, N. D., \& Lubenets, A. P. (1984). Modern direction of improving knockout of liquid glass mixtures. Foundry, (2), 17-18

11. Krutilin, A. N., Guminsky, Yu. Yu., \& Rusevich, O. A. (2018). Improving the efficiency of using liquid glass mixture. Survey information. Part 1. Modification. Foundry, 1(90), 47-54

12. Belobrov, E. A., Karpenko, O. L., \& Belobrov, L. E. (2018). Let us remember forgotten tech- nologies: about knocking out liquid glass mixtures from castings. Casting of Ukraine, (6), 22-25

13. Krutilin, A. N., Guminsky, Yu. Yu., \& Rusevich, O. A. (2018). Improving the efficiency of using liquid glass mixture. Part 3. Nanodispersed materials. Foundry, 3(92), 31-35

14. Linetskiy, B. S., Melnik, O. V., Kantor, S. B., \& Kasyanov, I. M. (1983). Easy-removable low-waste liquid glass molding rods. Foundry, (1), 18-19

15. Zhukovsky, S. S., \& Borsuk, P. A. (1983). Prospects for the use of mixtures with liquid glass in casting production. Foundry, (1), 12-14

16. Goberis, S., \& Antonovich, V. (2002). The influence of additives on the properties of liquid glass compositions. Foundry, (8), 22-24

17. Rep'yakh, S. I., Solonenko, L. I., \& Biliy, O. P. (2019). The power and structure of the components in food-and-wild formal sums. Theory and practice of metallurgy, (1), 81-92

Солоненко Людмила Ігорівна, доцент, кандидат технічних наук, доцент кафедри технології та управління ливарними процесами, Одеський національний політехнічний університет (м. Одеса, Україна). ORCID ID: 0000-0003-2092-8044. E-mail: solonenkoli14@gmail.com

Реп'ях Сергій Іванович, доктор технічних наук, професор кафедри ливарного виробництва, Національна металургійна академія України (м. Дніпро, Україна). ORCID ID: 0000-0003-0203-4135. Email: 123rs@ua.fm

\section{МІЦНІСТЬ ПІЩАНО-РІДКОСКЛЯНИХ СУМІШЕЙ, ЩО СТРУКТУРУВАЛИ ПАРО-МІКРОХВИЛЬОВОЮ ОБРОБКОЮ}

Мета. Встановлення закономірностей впливу умов плакування кварцового піску рідким склом, параметрів паро-мікрохвильового затвердіння і терміну зберігання суміші на величину її межі міцності при стисненні в структурованому стані.

Методика. У дослідженнях використовували кварцовий пісок з вмістом глинистої складової не більше $0,5 \%$ за масою і переважним розміром піщинок 0,23 мм, плакований содовим натрієвим рідким склом 3 силікатним модулем $2,8 . . .3,0$ і питомою щільністю $1,43 \ldots 1,46$ г $/ \mathrm{cm}^{3}$. Для визначення навантаження руйнування структурованих сумішей при стисканні за способом паро-мікрохвильового затвердіння виготовляли зразки розмірами $\varnothing 50 \times 50$ мм і $\varnothing 30 \times 30$ мм. Випробування зразків проводили на приладі LRu-2e. Температуру сумішей вимірювали з похибкою $\pm 1{ }^{\circ} \mathrm{C}$.

Результати. Встановлено, що межа міцності при стисненні в результаті тривалого зберігання плакованого піску навіть в герметично закритій тарі зменшується в $2 \ldots 3$ рази в порівнянні з свіжовиготовленою сумішшю, що, ймовірно, обумовлено частковою карбонізацією рідкого скла в плакованому шарі. Рекомендовано для структурування піщано-рідкоскляної суміші за способом паромікрохвильового затвердіння використовувати свіжовиготовлений плакований кварцовий пісок 3 температурою $20 \ldots 26^{\circ} \mathrm{C}$. При цьому для плакування натрієвим рідким склом рекомендовано використовувати кварцовий пісок 3 вмістом води до 0,2\% (за масою) та вмістом вологи в затверділому рідкому склі не більше $2 . . .3 \%$ від маси гідратованого силікату натрію. Наведені описи та аналіз встановлених закономірностей.

Наукова новизна. Вперше встановлено, що плакування кварцового піску рідким склом для його подальшого структурування способом паро-мікрохвильового затвердіння слід здійснювати при утриманні в піску вологи не більше 0,2 \% (за масою) з наступним сушінням піску до вмісту вологи в затверділому рідкому склі не більше $2 . . .3$ \% від маси гідратованого силікату натрію. 
Практична цінність. Отримані дані будуть корисними в ливарному виробництві, а саме в області формоутворення піщано-рідкоскляних сумішей.

Ключові слова: піщано-рідкоскляна суміш, рідке скло, паро-мікрохвильове затвердіння, міцність, вологість, зберігання.

Solonenko Lyudmila Igorivna, Candidate of Technical Sciences, Senior Lecturer of the Department of Technology and Management of Foundry Processes, Odessa National Polytechnic University (Odessa, Ukraine). ORCID ID: 0000-0003-2092-8044. E-mail: solonenkoli14@gmail.com

Repyakh Sergei Ivanovich, Doctor of Technical Science, Professor of the Department of Foundry, National Metallurgical Academy of Ukraine (Dnipro, Ukraine). ORCID ID: 0000-0003-0203-4135. E-mail: 123rs@ua.fm

\section{STRENGTH OF SAND-LIQUID-GLASS MIXTURES STRUCTURED BY STEAM-MICROWAVE TREATMENT}

Purpose. Establishing the regularities of the influence of the conditions for cladding quartz sand with water glass, the parameters of steam-microwave hardening and the shelf life of the mixture on the value of its ultimate strength in compression in the structured state.

Methods. The studies used quartz sand with a clay component of less than $0.5 \%$ by weight and a predominant size of sand grains of $0.23 \mathrm{~mm}$, clad with soda sodium water glass with a silicate modulus of $2.8 \ldots 3.0$ and a specific gravity of $1.43 \ldots 1.46 \mathrm{~g} / \mathrm{cm}^{3}$. To determine the fracture load of structured mixtures in compression by the method of steam-microwave hardening, specimens with dimensions $\varnothing 50 \times 50 \mathrm{~mm}$ and $\varnothing 30 \times 30 \mathrm{~mm}$ were made. The samples were tested on an LRu-2e device. The temperature of the mixtures was measured with an error of $\pm 1{ }^{\circ} \mathrm{C}$.

Results. It has been established that the ultimate strength in compression as a result of long-term storage of clad sand, even in a hermetically sealed container, decreases 2...3 times compared with a freshly prepared mixture, which is due to the carbonization of water glass in the clad layer. It is recommended to use freshly prepared clad quartz sand with a temperature of $20 \ldots 26^{\circ} \mathrm{C}$ for structuring a sand-liquid-glass mixture by the method of steam-microwave hardening. At the same time, for cladding with sodium water glass, it is recommended to use quartz sand with a water content of up to $0.2 \%$ water (by weight) and dry it to a moisture content in the hardened water glass of no more than $2 \ldots 3 \%$ of the weight of hydrated sodium silicate. Descriptions and analysis of the established patterns are given.

Originality. It was established for the first time that the cladding of quartz sand with liquid glass for its subsequent structuring by the method of steam-microwave curing should be carried out with a moisture content in the sand of no more than $0.2 \%$ (by weight), followed by drying the sand to a moisture content in the hardened liquid glass of no more than $2 . . .3 \%$ by weight of hydrated sodium silicate.

Practical implications. The obtained data will be useful in foundry, namely in the field of shaping.

Key words: sand-liquid glass mixture, liquid glass, steam-microwave hardening, strength, humidity, storage.

Солоненко Людмила Игоревна, доцент, кандидат технических наук, доцент кафедры технологий и управления литейными процессами, Одесский национальный политехнический университет (Одесса, Украина). ORCID ID: 0000-0003-2092-8044. E-mail: solonenkoli14@gmail.com

Репях Сергей Иванович, доктор технических наук, профессор кафедры литейного производства, Национальная металлургическая академия Украины (Днепр, Украина). ORCID ID: 0000-00030203-4135. E-mail: 123rs@ua.fm

\section{ПРОЧНОСТЬ ПЕСЧАНО-ЖИДКОСТЕКОЛЬНЫХ СМЕСЕЙ, СТРУКТУРИРОВАННЫХ ПАРО-МИКРОВОЛНОВОЙ ОБРАБОТКОЙ}

Цель. Установление закономерностей влияния условий плакирования кварцевого песка жидким стеклом, параметров паро-микроволнового отверждения и срока хранения смеси на величину ее пре- 
дела прочности при сжатии в структурированном состоянии.

Методика. В исследованиях использовали кварцевый песок с содержанием глинистой составляющей мене $0,5 \%$ по массе и преимущественным размером песчинок 0,23 мм, плакированный содовым натриевым жидким стеклом с силикатным модулем 2,8...3,0 и удельной плотностью $1,43 \ldots 1,46$ г $/ \mathrm{cm}^{3}$. Для определения нагрузки разрушения структурированных смесей при сжатии по способу паро-микроволнового отверждения изготавливали образцы размерами $\varnothing 50 \times 50$ мм и $\varnothing 30 \times 30$ мм. Испытания образцов проводили на приборе LRu-2e. Температуру смесей измеряли с погрешностью $\pm 1{ }^{\circ} \mathrm{C}$.

Результаты. Установлено, что предел прочности при сжатии в результате длительного хранения плакированного песка даже в герметично закрывающейся таре уменьшается в $2 \ldots 3$ раза по сравнению со свежеприготовленной смесью, что обусловлено карбонизацией жидкого стекла в плакированном слое. Рекомендовано для структурирования песчано-жидкостекольной смеси по способу паромикроволнового отверждения использовать свежеприготовленный плакированный кварцевый песок с температурой $20 \ldots 26^{\circ} \mathrm{C}$. При этом для плакирования натриевым жидким стеклом рекомендовано использовать кварцевый песок с содержанием воды до 0,2 \% воды (по массе) и сушить его до содержания влаги в затвердевшем жидком стекле не более $2 . . .3 \%$ от массы гидратированного силиката натрия. Приведены описания и анализ установленных закономерностей.

Научная новизна. Впервые установлено, что плакирование кварцевого песка жидким стеклом для его последующего структурирования способом паро-микроволнового отверждения следует осуществлять при содержании в песке влаги не более $0,2 \%$ (по массе) с последующей сушкой песка до содержания влаги в затвердевшем жидком стекле не более $2 . . .3 \%$ от массы гидратированного силиката натрия.

Практическая ценность. Полученные данные будут полезными в литейном производстве, а именно в области формообразования.

Ключевые слова: песчано-жидкостекольная смесь, жидкое стекло, паро-микроволновое отверждение, прочность, влажность, хранение.

Рукопис надійшов 02.07.2020 p. 